\title{
E-cadherin and Adenomatous Polyposis Coli Mutations Are Synergistic in Intestinal Tumor Initiation in Mice
}

\author{
RON SMITS,* PATRICIA RUIZ, ${ }^{\ddagger}$ SALVADOR DIAZ-CANO,§ ARNE LUZ,§ \\ SHANTIE JAGMOHAN-CHANGUR,* COR BREUKEL, ${ }^{*}$ CARMEN BIRCHMEIER, ${ }^{*}$ \\ WALTER BIRCHMEIER, ${ }^{\ddagger}$ and RICCARDO FODDE* \\ *Medical Genetics Center, Department of Human and Clinical Genetics, Leiden University Medical Center, Leiden, The Netherlands; \\ †Max Delbrück Center for Molecular Medicine, Berlin, Germany; and §GSF-forschungszentrum für Umwelt und Gesundheit GmbH, \\ Department of Pathology, Neuherberg, Germany
}

\section{See editorial on page 1161.}

Background \& Aims: Inactivation of the adenomatous polyposis coli $(A P C)$ gene is observed at early stages of intestinal tumor formation, whereas loss of E-cadherin is usually associated with tumor progression. Because both proteins compete for the binding to $\beta$-catenin, an essential component of the Wht signaling pathway, reduction of E-cadherin levels in an Apc mouse model could influence both tumor initiation and progression. In addition, loss or haploinsufficiency of E-cadherin may affect tumorigenesis by altering its cell-adhesive and associated functions. Methods: Apc1638N mice were bred with animals carrying a targeted E-cadherin knockout mutation. Results: Double heterozygous animals showed a significant 9-fold and 5-fold increase of intestinal and gastric tumor numbers, respectively, compared with Apc1638N animals. The intestinal tumors of both groups showed no significant differences in grading and staging. Loss of heterozygosity analysis at the Apc and E-cadherin loci in both intestinal and gastric $A p c^{+/ 1638 N /}$

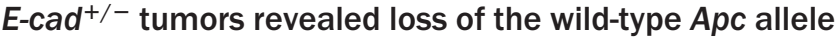
in most cases, whereas the wild-type E-cadherin allele was always retained. This was supported by a positive, although reduced, staining for E-cadherin of intestinal tumor sections. Conclusions: Introduction of the E-cadherin mutation in Apc1638N animals enhances Apcdriven tumor initiation without clearly affecting tumor progression.

$\mathrm{M}$ alignant tumors are the result of accumulation of several genetic alterations. Several lines of evidence indicate that mutations of the adenomatous polyposis coli $(A P C)$ gene represent one of the earliest genetic events in intestinal tumor development. First, germline APC mutations are responsible for familial adenomatous polyposis, a dominant condition characterized by multiple colorectal adenomatous polyps in the colon and rectum. ${ }^{1,2}$ Germline mutations in the mouse Apc gene also result in a dominant predisposition to the development of multiple tumors in the intestine and elsewhere. ${ }^{3-6}$ In accordance with Knudson's 2-hit hypothesis, somatic mutations at the wild-type APC allele can be detected in most intestinal tumors of both human and murine origin. ${ }^{5,7-10}$ Lastly, the majority of sporadic colorectal tumors carry APC mutations with similar frequencies between early and more advanced tumor stages. ${ }^{11}$

The APC gene encodes a 312-kilodalton protein shown to participate in several cellular processes, including cell cycle regulation, apoptosis, cell adhesion, cell migration, microtubule assembly, and signal transduction. ${ }^{12}$ We showed recently that the tumor-suppressing function of APC resides in its capacity to properly regulate intracellular $\beta$-catenin levels, whereas its $\mathrm{COOH}$ terminal domains seem to be less relevant for its function in development and tumorigenesis. ${ }^{13} \beta$-Catenin functions as a signaling molecule within the Wnt signal transduction pathway by associating in the nucleus with members of the lymphoid enhancer factor/T-cell factor family of transcriptional activators, thereby modulating the transcription of target genes. ${ }^{14}$ In the absence of a Wnt-signal, APC promotes down-regulation of $\beta$-catenin, thereby preventing its signaling activity. ${ }^{15}$ As a result of APC mutations, $\beta$-catenin constitutively transduces signals to the nucleus. Accordingly, oncogenic $\beta$-catenin mutations that make it resistant to proteolytic degradation are found in sporadic colorectal tumors without $A P C$ mutations. ${ }^{16}$

In addition to its role in the Wnt-signaling pathway, $\beta$-catenin binds to the cytoplasmic domain of E-cadherin, thus mediating cell-to-cell interactions by linking it to the actin cytoskeleton. ${ }^{17-20}$ Whereas loss of APC

Abbreviations used in this paper: APC, adenomatous polyposis coli; $\mathrm{LOH}$, loss of heterozygosity.

(C) $\mathbf{2 0 0 0}$ by the American Gastroenterological Association 0016-5085/00/\$10.00 doi:10.1053/gast.2000.18162 
function seems to be involved in initiation of intestinal tumor development, inactivation of E-cadherin is generally associated with later stages of tumor progression because disruption of E-cadherin function correlates with increased tumor invasiveness. ${ }^{21-23}$ Therefore, by reducing the expression of E-cadherin in animals with a targeted Apc mutation, one may expect an increased invasive potential of the developing intestinal tumors. However, because $\beta$-catenin appears to exist in a state of dynamic equilibrium with E-cadherin and $\mathrm{Apc},{ }^{24,25}$ reducing Ecadherin levels may also potentially affect intestinal tumor initiation by increasing the amount of intracellular $\beta$-catenin available for signaling. Reduction of E-cadherin levels may also contribute to tumorigenesis by affecting its cell-adhesive and associated functions. ${ }^{26-29}$ A possible role for E-cadherin in tumor initiation is supported by the presence of germline mutations in families predisposed to gastric cancer development ${ }^{30-32}$ and mutations in early-stage gastric and breast cancers. ${ }^{33-35}$

To address the issue of "cross talk" between cell-to-cell adhesion and signal transduction, we have bred the Apc1638N model ${ }^{4,6}$ with mice carrying a targeted $E$-cadherin mutation. ${ }^{36}$ The double heterozygous $A p c^{+/ 1638 \mathrm{~N}} / E$-cad ${ }^{+/-}$mice show a marked increase in tumor number along the upper gastrointestinal tract without any clear modification of tumor invasivity or malignant potential. These results indicate that haploinsufficiency at the E-cadherin locus is synergistic with mutation of the $A p c$ gene in gastrointestinal tumor initiation.

\section{Materials and Methods}

\section{Animals}

C57BL/6JIco(B6)-Apc $c^{+/ 1638 \mathrm{~N}}$ females were mated with E-cadherin ${ }^{+-}$males of mixed Ola129/129J genetic background to obtain $A p c^{+/ 1638 \mathrm{~N} / E-c a d^{+/-}}$and $A p c^{+/ 1638 \mathrm{~N} / E-c a d^{+/+}}$ mice on an F1(B6xOla129/129J) background. The same cross also resulted in $A p c^{+/+} / E-c a d^{+/-}$and $A p c^{+/+} / E-c a d^{+/+}$littermates serving as controls. The experiments were approved by the animal experimental commission (UDEC) of the Medical Faculty of the Leiden University (Leiden, The Netherlands; permission 9613).

\section{Gross Study and Tissue Processing}

All animals were killed between 6 and 9 months of age, after which the entire intestine was removed and opened longitudinally. Sections of approximately $10 \mathrm{~cm}$ were spread out flat on filter paper, fixed overnight at $4^{\circ} \mathrm{C}$ in Notox (Earth Safe Industries, Inc., Bellemead, NJ), and transferred to $70 \%$ ethanol. The size and location of macroscopically visible tumors were determined, followed by resection and embedding of lesions in paraffin according to standard procedures. In addition, a number of freshly isolated tumors were snap-frozen in Tissue-tek OCT compound (Sakura B.V., Zoeterwoude, The Netherlands). Cutaneous cysts and desmoids were counted as described previously. ${ }^{6}$ Liver and lungs of all animals were investigated for the presence of metastases by macroscopic and microscopic analysis. Tumor numbers were statistically evaluated by the Mann-Whitney exact test.

\section{Histopathologic Classification of Gastrointestinal Tumors}

Tumors were classified according to standard criteria, ${ }^{37}$ considering a given tumor malignant only if invasion (lamina propria or beyond) was present. The invasion was defined by the presence of stromal fibroblastic reaction (desmoplasia). Tumors were graded according to the extension of glandular differentiation, ${ }^{38}$ and staged according to the depth of invasion in the intestinal wall and the presence of lymph node or systemic metastases. Both lungs and liver were embedded in toto, and serial H\&E-stained sections were screened for the presence of microscopic metastases by 2 independent observers (S.D.-C. and A.L.).

\section{Tumor DNA Isolation}

Tumor DNA isolation from microdissected paraffin or cryosections was performed essentially as previously described. ${ }^{10}$ Briefly, six $16-\mu \mathrm{m}$-thick sections were placed on glass slides, deparaffinized, rehydrated, and briefly stained with hematoxylin. The area containing the tumor cells was subsequently microdissected under a dissection microscope using as reference an H\&E-stained 5- $\mu \mathrm{m}$ section. The isolated neoplastic tissue was transferred in $250-\mu \mathrm{L}$ extraction buffer $(10 \mathrm{mmol} / \mathrm{L}$ Tris-HCl $[\mathrm{pH}$ 8.0], $100 \mathrm{mmol} / \mathrm{L} \mathrm{NaCl}, 25$ $\mathrm{mmol} / \mathrm{L}$ EDTA, $0.5 \%$ sodium dodecyl sulfate, and $300 \mu \mathrm{g} / \mathrm{mL}$ proteinase $\mathrm{K}$ ) and incubated at $55^{\circ} \mathrm{C}$ for 40 hours. A second aliquot of $60 \mu \mathrm{g}$ of proteinase $\mathrm{K}$ was added after 20 hours of incubation. Cellular proteins were removed by a phenol/chloroform and chloroform extraction followed by a 30-minute precipitation at $-20^{\circ} \mathrm{C}$ with $125 \mu \mathrm{L} 7.5 \mathrm{~mol} / \mathrm{L} \mathrm{NH}_{4} \mathrm{Ac}, 20$ $\mu \mathrm{g}$ glycogen, and $625 \mu \mathrm{L}$ ethanol. The precipitate was resuspended in $50 \mu \mathrm{L} \mathrm{TE}^{-4}(10 \mathrm{mmol} / \mathrm{L}$ Tris- $\mathrm{HCl}[\mathrm{pH} 8.0]$ and 0.1 $\mathrm{mmol} / \mathrm{L}$ EDTA).

\section{Loss of Heterozygosity Analysis at the Apc and E-cadherin Locus}

Loss of the wild-type $A p c$ and E-cadherin allele was analyzed by amplifying in a single reaction both the wild-type and targeted alleles. ${ }^{10}$ The following primers were used for E-cadherin: 1533 (5'-CCTCTCCTTTGACAGGAACCTCCGT-3') and 1534 (5'-CAGCCCAGAGGTGAGCACACTGATG-3'), resulting in a 190 -base pair (bp) product diagnostic of the wild-type allele, and E-cadneo71 (5'GCAAAACCACACTGCTCGAC- $3^{\prime}$ ) that in combination with 1533 results in a 198-bp product diagnostic of the targeted allele. For the $A p c$ locus, the following primers were used: Apc-A2 (5'-TCAGCCATGCCAACAAAGTCA-3') and 
Apc-C2 (5'-GGAAAAGTTTATAGGTGTCCCTTCT-3'), resulting in a 216-bp product diagnostic of the wild-type allele, and Neo3 (5'-CACTTCATTCTCAGTATTGTTTTG- $3^{\prime}$ ) that in combination with $A p c-A 2$ results in a 227 -bp product diagnostic of the targeted $A p c 1638 \mathrm{~N}$ allele. A radioactive polymerase chain reaction was performed using $2.5 \mu \mathrm{L}$ of tumor DNA or $2.5 \mu \mathrm{L}$ of normal DNA samples, the latter isolated from normal intestinal or gastric epithelium surrounding the tumor. The amplification was performed in a $20-\mu \mathrm{L}$ volume, containing $10 \mathrm{mmol} / \mathrm{L}$ Tris- $\mathrm{HCl}(\mathrm{pH} 8.9), 50 \mathrm{mmol} / \mathrm{L}$ $\mathrm{KCl}, 2.5 \mathrm{mmol} / \mathrm{L} \mathrm{MgCl}_{2}, 10 \%$ glycerol, $200 \mu \mathrm{g} / \mathrm{mL}$ bovine serum albumin, $0.01 \%$ gelatin, $0.2 \mathrm{mmol} / \mathrm{L}$ of each deoxyadenosine triphosphate, deoxythymidine triphosphate, and deoxyguanosine triphosphate, $0.05 \mathrm{mmol} / \mathrm{L}$ deoxycytidine triphosphate, $0.25 \mu \mathrm{Ci}\left[{ }^{32} \mathrm{P}\right]$ deoxycytidine triphosphate (3000 $\mathrm{Ci} / \mathrm{mmol}$ ), $0.2 \mathrm{U}$ Taq polymerase, and $10 \mathrm{pmol}$ of each primer. The reactions were heated for 5 minutes at $94^{\circ} \mathrm{C}$ followed by 32 polymerase chain reaction cycles at $94^{\circ} \mathrm{C}$ for 30 seconds, $55^{\circ} \mathrm{C}$ for 60 seconds, and $72^{\circ} \mathrm{C}$ for 90 seconds. Amplified fragments were resolved on a denaturing $6 \%$ polyacrylamide gel and dried on paper, and the number of counts per allele was determined on a phosphor imager. Subsequently, the number of counts of the larger allele was divided by the counts of the smaller allele to obtain an allelic ratio. A mean allelic ratio was calculated for all the normal controls. This value was used to generate a comparative ratio $>1.0$ by dividing the tumor allelic ratio by the mean normal allelic ratio. A comparative ratio $>1.5$ was interpreted as significant, i.e., indicative of loss of the wild-type allele.

\section{Immunohistochemical Analysis}

Frozen tissue sections $(7 \mu \mathrm{m})$ were fixed with acetone for 10 minutes and incubated for 30 minutes in phosphatebuffered saline (PBS)/1\% bovine serum albumin to block nonspecific binding. Subsequently, sections were incubated for 1 hour with undiluted hybridoma supernatant of the DECMA antibody (Sigma, Zwijndrecht, The Netherlands) recognizing an epitope within residues 407-434 of E-cadherin located close to the membrane proximal part of the extracellular domain. ${ }^{39,40}$ Sections were also incubated with a 1:400 dilution of a rabbit polyclonal antibody directed against the $\mathrm{COOH}$ terminus of $\beta$-catenin. ${ }^{24}$ After 3 washes with PBS, the primary antibodies were visualized with a fluorescein isothiocyanate-conjugated goat anti-rat IgG antibody and Cy3-conjugated goat anti-rabbit antibody (Jackson ImmunoResearch Laboratories (West Grove, PA).
Immunohistochemical staining of E-cadherin in paraffin sections was performed with a monoclonal antibody (clone 34) raised against the $\mathrm{COOH}$-terminal 150 residues of $\mathrm{E}$-cadherin (Transduction Laboratories, Lexington, KY). Sections were rehydrated, blocked in PBS containing 5\% nonfat dry milk, and subsequently incubated for 16 hours at $4{ }^{\circ} \mathrm{C}$ with the primary antibody diluted $1: 100$ in $\mathrm{PBS} / 5 \%$ nonfat dry milk. After 3 washes in PBS containing 0.2\% Tween 20, the sections were incubated for 1 hour in a 1:250 dilution of a horseradish peroxidase-conjugated $\mathrm{F}\left(\mathrm{ab}^{\prime}\right)_{2}$ fragment goat anti-mouse antibody (Jackson ImmunoResearch Laboratories). The peroxidase reaction was developed with $0.01 \%$ hydrogen peroxide in $0.05 \%$ diaminobenzidine tetrahydrochloride in $50 \mathrm{mmol} / \mathrm{L}$ Tris-HCl (pH 7.6).

\section{Results}

\section{Tumor Size and Numbers in the Gastrointestinal Tract of $\mathrm{Apc}^{+/ 1638 \mathrm{~N}} / \mathrm{E}_{-\mathrm{Cad}^{+/-}}$Mice}

To study the interaction between cell-to-cell adhesion and signal transduction in the gastrointestinal epithelium, we have bred $A p c 1638 \mathrm{~N}$ mice ${ }^{4,6}$ with mice carrying a targeted E-cadherin mutation. ${ }^{36}$ The gastrointestinal tracts of the compound $A p c^{+/ 1638 \mathrm{~N}} / E-c a d^{+/-}$mice were analyzed for the presence of tumors and compared with their $A p c^{+/ 1638 \mathrm{~N}}, E-c a d^{+/-}$, and wild-type littermates. All animals were killed between 6 and 9 months of age (mean age for all groups, 7.5 months). As expected, no tumors were observed in wild-type $(\mathrm{n}=10)$ and $E-\mathrm{cad}^{+/-}(\mathrm{n}=9)$ animals, whereas $A p c^{+/ 1638 \mathrm{~N}}$ mice $(\mathrm{n}=17)$ had an average of 1.24 tumors per animal in the small intestine. A dramatic effect on tumor multiplicity along the gastrointestinal tract was observed in the compound heterozygous $A p c^{+/ 1638 \mathrm{~N}} / E-c a d^{+/-}$animals (Table 1). The number of small intestinal tumors in these mice $(\mathrm{n}=18)$ showed a significant 9-fold increase (average, 11.3 tumors per animal) compared with the $A p c^{+/ 1638 \mathrm{~N}}$ group $(P<0.0001$, Mann-Whitney test). A similar increase was observed for gastric tumors. Only 4 of 11 $A p c^{+/ 1638 \mathrm{~N}}$ mice had a single gastric tumor, but all 14 investigated $A p c^{+/ 1638 \mathrm{~N}} / E-c a d^{+/-}$animals had developed at least 1 tumor. The average number of macroscopically detectable gastric lesions was increased by more than

Table 1. Gastrointestinal Tumor Numbers

\begin{tabular}{|c|c|c|c|c|c|c|}
\hline \multirow[b]{2}{*}{ Genotype } & \multicolumn{3}{|c|}{ Intestine } & \multicolumn{3}{|c|}{ Stomach } \\
\hline & No. studied & No. of tumors & Range & No. studied & No. of tumors & Range \\
\hline$+/+$ & 10 & 0 & & 10 & 0 & \\
\hline${\mathrm{E}-\mathrm{Cad}^{+/-}}^{-}$ & 9 & 0 & & 9 & 0 & \\
\hline$A p c^{+/ 1638 \mathrm{~N}}$ & 17 & $1.24 \pm 1.1$ & $0-4$ & 11 & $0.36 \pm 0.5$ & $0-1$ \\
\hline $\mathrm{Apc}^{+/ 1638 \mathrm{~N}} / \mathrm{E}^{-\mathrm{Cad}^{+/-}}$ & 18 & $11.3 \pm 5.1$ & $2-24$ & 14 & $2.0 \pm 1.4$ & $1-5$ \\
\hline
\end{tabular}




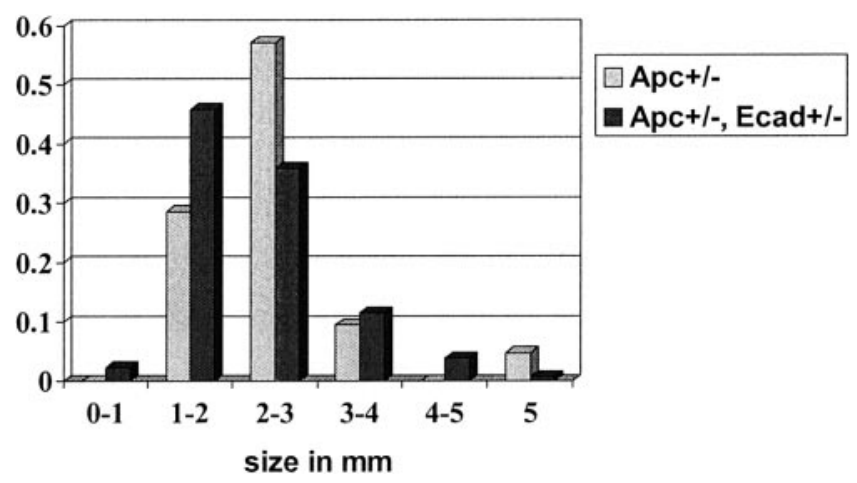

Figure 1. Histogram showing the size distribution of intestinal tumors

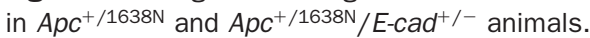

5-fold, from 0.36 to 2.0 tumors per animal $(P<0.001$, Mann-Whitney test). Cutaneous cysts and desmoid lesions, characteristic of the Apc1638N mutation, ${ }^{6}$ were not affected by the $E$-cadherin mutation (data not shown).

In contrast with the increase in tumor numbers, tumor size was not clearly affected by the E-cadherin haploinsufficiency. The $A p c^{+/ 1638 \mathrm{~N}}$ tumors $(\mathrm{n}=21)$ had grown to an average diameter of $2.32 \pm 0.83 \mathrm{~mm}$, which is similar to the $2.01 \pm 0.83 \mathrm{~mm}$ observed in 124 tumors derived from $11 A p c^{+/ 1638 \mathrm{~N} / E-c a d^{+/-}}$animals. As shown in Figure 1, also the distribution in tumor size between both groups is comparable, whereby the tumors of the $A p c^{+/ 1638 \mathrm{~N} / E-c a d^{+/-}}$animals even show a slight tendency toward smaller tumors. Hence, these results are indicative of an effect of E-cadherin haploinsufficiency on gastrointestinal tumor multiplicity in the Apc1638N model, rather than on the rate at which these tumors grow.

\section{Morphology and Malignant Potential of the Gastrointestinal Tumors}

Detailed histologic analysis of $15 A p c^{+/ 1638 \mathrm{~N}}$ small intestinal tumors showed evidence of stromal invasion in all cases. The same was observed in 117 of $124 \mathrm{Apc}^{+/ 1638 \mathrm{~N} /}$ $E$-cad ${ }^{+/-}$tumors. Most of the lesions found in both genotypes can therefore be regarded as carcinomas. Submucosal invasion was observed in 10 of $15 A p c^{+/ 1638 \mathrm{~N}}$ tumors and 62 of $124 A p c^{+/ 1638 \mathrm{~N} / E-c a d^{+/-}}$tumors. No diffuse growth pattern characteristic for a loss of adhesive function was observed in any of the tumors. Serial sectioning of the liver and lungs could not detect any metastases, neither in the $A p c^{+/ 1638 \mathrm{~N}}$ group nor in the group with additional $E$-cadherin mutation. Although we cannot exclude the presence of micrometastases, the absence of any identifiable metastasis in the double heterozygous animals with the 9-fold higher tumor burden suggests that this is an uncommon event. Therefore, both the degree of local invasion and the metastatic potential of the $A p c 1638 \mathrm{~N}$ tumors are not affected by the $E$ cadherin mutation.

All gastric tumors were located in the fundus and pyloric region. The lesions of both groups showed variable proportions of gland-like structures, indicating an intestinal phenotype without any evidence of diffuse tumor growth. Examples of gastric lesions are shown in Figure 2.

\section{E-cadherin Is Expressed in Tumors of Both Genotypes}

We have previously shown that in the majority of $A p c 1638 \mathrm{~N}$ intestinal tumors, the wild-type copy of $A p c$ is somatically lost. ${ }^{10,41,42}$ To assess whether loss of the wild-type $E$-cadherin allele underlies tumor formation in double heterozygous $A p c^{+/ 1638 \mathrm{~N}} / E-c a d^{+/-}$animals, 16 intestinal and 16 gastric tumors were investigated by $\mathrm{LOH}$ analysis. Twelve of 16 intestinal tumors tested showed loss of the wild-type $A p c$ allele. Gastric tumors showed loss of the wild-type $A p c$ allele in 9 of 16 cases with borderline results in 2 other tumors. In contrast, all gastric and intestinal tumors showed retention of the wild-type E-cadherin allele (Figure 3).

Immunohistochemical analysis was performed on cryosections of tumors from both genotypes with the rat monoclonal antibody DECMA, directed against residues 407-434 of E-cadherin. ${ }^{39,40}$ Expression could be detected in all tumors, although the staining intensity was clearly reduced compared with the normal intestinal mucosa (Figure 4). The staining pattern was similar for tumors of both genotypes with no obvious quantitative differences. This was also the case for a rabbit polyclonal $\beta$-catenin antibody (Figure 4).

Both the $\mathrm{LOH}$ and immunostaining results with the DECMA antibody suggest that wild-type E-cadherin is still expressed in $A p c^{+/ 1638 \mathrm{~N} / E-c a d^{+/-}}$tumors. However, it is plausible that a truncating mutation in the second half of the protein disrupts E-cadherin function. Therefore, 10 paraffin-embedded $A p c^{+/ 1638 \mathrm{~N} / E-c a d^{+/-}}$intestinal tumors were stained with a monoclonal antibody raised against the $\mathrm{COOH}$-terminal 150 residues of $\mathrm{E}$ cadherin. All tumors had retained immunoreactivity, strongly suggesting that wild-type E-cadherin is still present in the majority of tumors (data not shown).

\section{Discussion}

Complete loss of E-cadherin function is generally associated with the acquisition of an invasive phenotype. $^{21-23}$ However, inactivation has also been observed in early-stage gastric and lobular breast cancers characterized by a diffuse growth pattern. ${ }^{33-35}$ We now show 

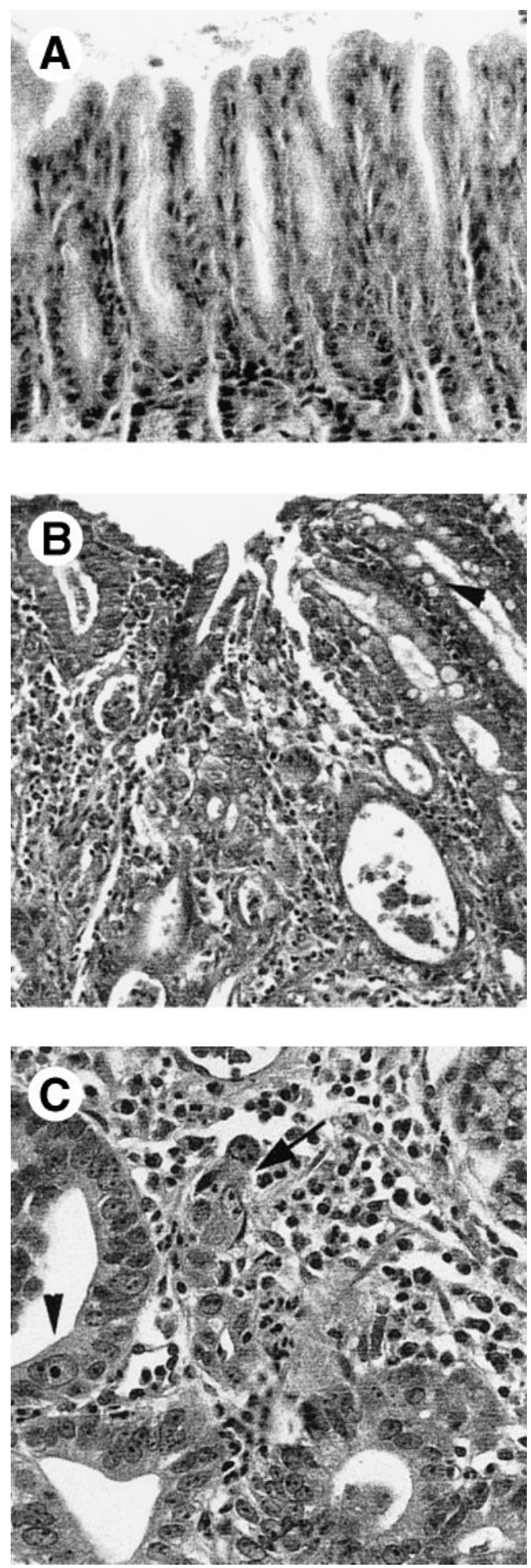

Figure 2. Example of a gastric lesion observed in an $A p c^{+/ 1638 N} / E-$ $\mathrm{cad}^{+/-}$animal. (A) Normal gastric epithelium from the pyloric region of the stomach. $(B)$ The upper part shows an invasive intestinal-type adenocarcinoma. Gastric mucosa epithelium shows interspersed goblet cells as sign of intestinal metaplasia (arrowhead) and regenerative gastric epithelium. $(C)$ A detail of an invasive adenocarcinoma revealing pleomorphic cells with prominent nucleoli and tubular formation (arrowhead). The irregular glands in the center represent early invasion of the stroma (arrow). that heterozygosity for an inactivating E-cadherin mutation in Apc1638N animals results in a strong increase of the number of gastrointestinal tumors without clearly affecting malignant potential. Interestingly, no $\mathrm{LOH}$ at the E-cadherin locus was observed in the corresponding tumors, and E-cadherin expression was still detectable by immunohistochemistry. No diffuse growth pattern was observed in any of the tumors, as is frequently the result of a complete inactivation of E-cadherin function. ${ }^{43-45}$ Thus, introduction of the E-cadherin mutation in Apc1638N animals mainly seems to affect tumor formation rather than tumor progression.

A number of not mutually exclusive mechanisms can be envisaged to explain this increase in tumor multiplicity. First, E-cadherin haploinsufficiency could enhance $A p c$-driven tumorigenesis by increasing the pool of $c y$ toplasmic $\beta$-catenin available for Wnt signaling. Defects in the Wnt signaling pathway underlie intestinal tumor formation, as indicated by the presence of mutations in either APC or $\beta$-catenin in most colorectal cancers. ${ }^{7,16}$ We have recently shown that (1) the tumor-suppressing activity of $A p c$ lies in its ability to prevent $\beta$-catenin to signal through the Wnt pathway, ${ }^{13}$ and (2) that $A p c$ mutations are selected upon their capacity to inactivate the $\beta$-catenin down-regulating activity in intestinal tumorigenesis in the mouse. ${ }^{46}$ Tumor formation is most efficient if all Apc domains involved in $\beta$-catenin regulation are removed. In other words, once both copies of $A p c$ become mutated, a stronger $\beta$-catenin/Wnt signal to

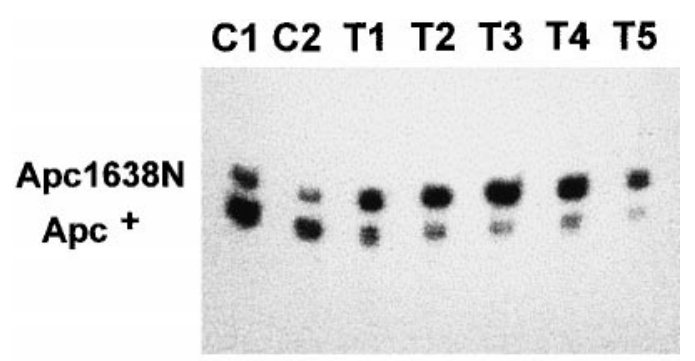

\section{C1 C2 T1 T2 T3 T4 T5}

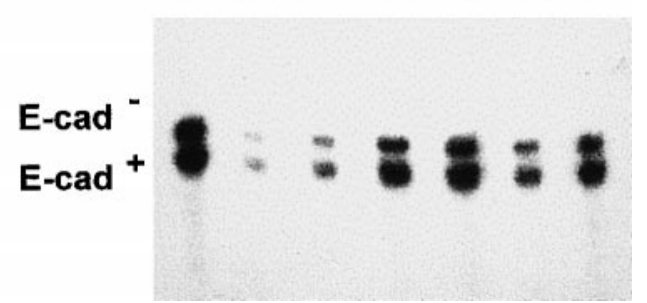

Figure 3. Example of tumor $\mathrm{LOH}$ analysis at the $A p c$ and E-cadherin locus. C1-C2, DNA isolated from normal intestinal mucosa; T1-T5, DNA isolated from tumor samples. All tumors show a clear loss of the wild-type $A p c$ allele, but all have retained the wild-type E-cadherin allele. 

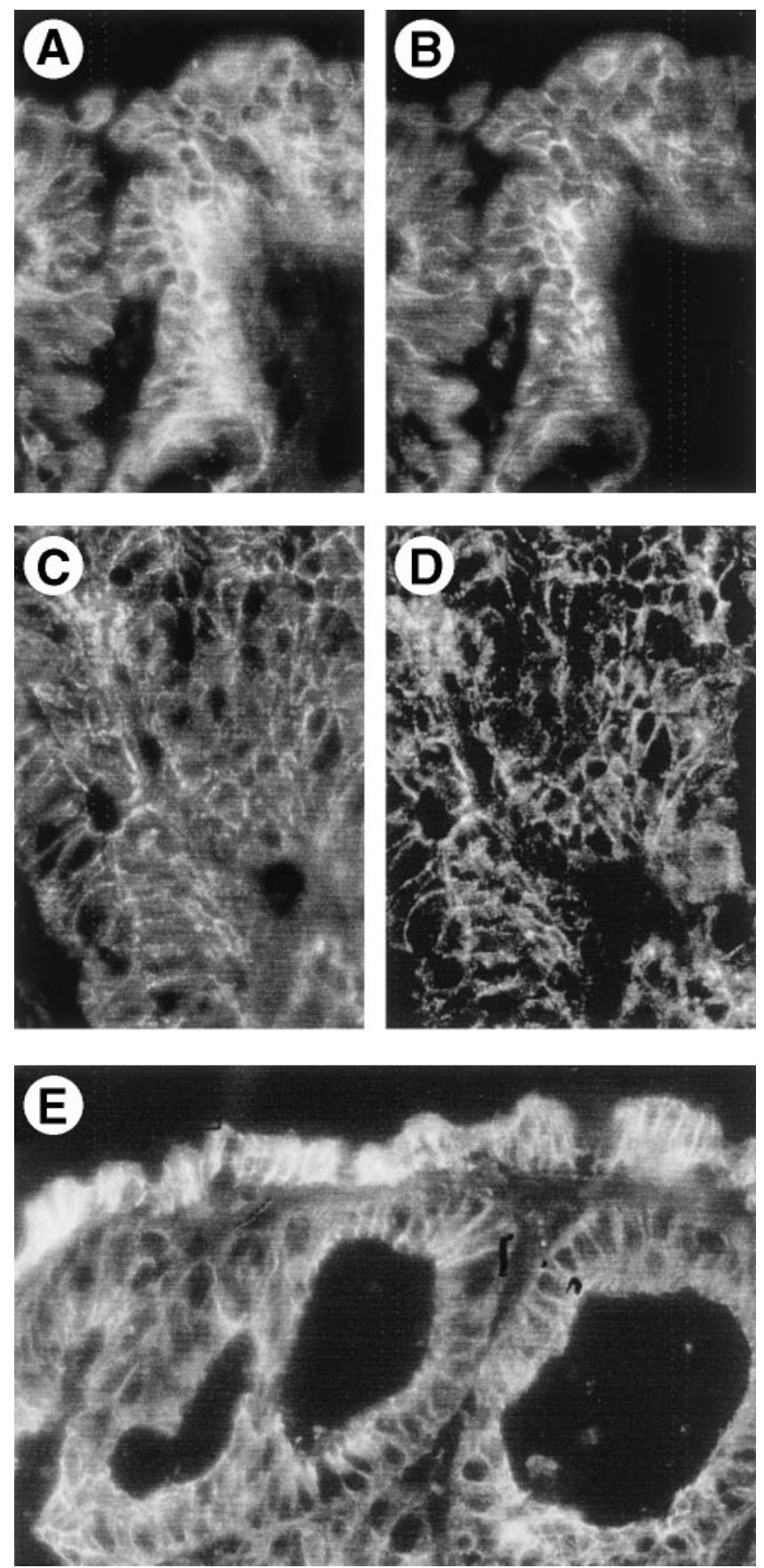

Figure 4. Immunohistochemical staining of E-cadherin in intestinal tumors derived from $(A) A p c^{+/ 1638 N}$ or $(C) A p C^{+/ 1638 N} / E_{-C a d^{+/-}}$animals. $(B$ and $D$ ) Sections derived from the same tumors were also stained for $\beta$-catenin. $(E)$ E-cadherin staining of an intestinal tumor

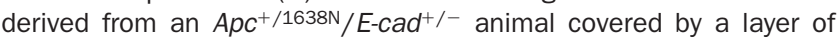
normal intestinal epithelium. Membranous staining for E-cadherin remains in tumor cells, although the expression level is clearly reduced compared with the normal intestinal epithelium.

the nucleus increases the chance of intestinal tumor formation.

Although $\beta$-catenin has distinct roles in cell adhesion and signaling, ${ }^{47-49}$ several investigations have shown that cadherins may act as modulators of the Wnt signal- ing pathway. Increasing the level of cadherin in Xenopus embryos depleted the cytoplasmic pool of $\beta$-catenin and interfered with Wnt signal-mediated axis formation. ${ }^{47,50}$ Similar studies in Drosophila showed that overexpression of cadherin mimicked the wingless phenotype observed when Armadillo, the Drosopbila homologue of $\beta$-catenin, is mutated. This defect could be rescued by increasing Armadillo levels. ${ }^{48}$ In colorectal cancer cells, expression of cadherin derivatives inhibited $\beta$-catenin-mediated transactivation of a Wnt reporter. ${ }^{51,52}$ The opposite effect, i.e., increasing the signaling pool of $\beta$-catenin by reducing cadherin levels, has also been shown. ${ }^{53}$ Haploinsufficiency for cadherin in Drosophila diminished the wingless defect of an intermediate mutant of Armadillo, presumably by releasing some of the normally membrane-bound Armadillo and making it available for signaling. Thus, a considerable amount of experimental evidence supports a substantial role for cadherins in modulating Wnt signal-related processes. Accordingly, the reduced amount of E-cadherin in $A p c^{+/ 1638 \mathrm{~N}} / E-c a d^{+/-}$ animals could result in an enlarged intracellular pool of $\beta$-catenin, thus enhancing Wnt signaling and the likelihood of tumor formation to occur. The increased signaling activity most likely becomes apparent only once Apc is temporarily inactivated by an extracellular Wnt signal or when both copies of $A p c$ become mutated. That Apc inactivation still appears to be a rate-limiting step for tumor development is supported by the loss of the wild-type $A p c$ allele in 9-11 of 16 gastric and 12 of 16 intestinal $A p c^{+/ 1638 \mathrm{~N} / E-c a d^{+/-}}$tumors, similar to $\mathrm{LOH}$ frequencies previously observed in $A p c 1638 \mathrm{~N}$ tumors on various genetic backgrounds. ${ }^{10,41,42}$ Moreover, heterozygosity at the E-cadherin locus itself is not sufficient to trigger tumorigenesis, as confirmed by the lack of tumors in $E$-cad ${ }^{+/-}$mice. However, no clear increase in $\beta$-catenin levels was observed in the $A p c^{+/ 1638 \mathrm{~N} / E-c a d^{+/-}}$tumors in comparison with $A p c^{+/ 1638 \mathrm{~N}}$ tumors, although it should be noted that the immunofluorescence method used is not appropriate for quantitative comparisons. Further experimentation is needed to show that the reduced E-cadherin levels affect Wnt signaling.

E-cadherin participates in a complex network of interactions between adhesion receptors, cytoskeletal proteins, and several signaling pathways. ${ }^{26-29}$ Therefore, changes at adherens complexes may result in alterations of cell shape and polarity, proliferation, cell motility, attachment to the extracellular matrix, and cytoskeletal organization. This was also shown by the introduction of a dominant negative $\mathrm{N}$-cadherin transgene in the murine intestinal tract. ${ }^{54}$ Expression of the transgene interfered with normal cadherin function, resulting in a reduced 
epithelial barrier function, altered proliferation, migration, and apoptosis along the crypt-villus axis, leading to inflammatory bowel disease and development of adenomas. In the normal intestinal mucosa of $A p c^{+/ 1638 \mathrm{~N}} / E-$ $\mathrm{cad}^{+/-}$animals, no such abnormalities were observed, suggesting that sufficient E-cadherin function is available to support its normal functions. Nevertheless, we cannot exclude that an undetected change in cell-to-cell adhesion and subsequent changes in cellular functions may be responsible for the observed increase in tumor numbers.

The 5-fold increase of gastric tumors in $A p c^{+/ 1638 \mathrm{~N} / E \text { - }}$ $\mathrm{cad}^{+/-}$mice is interesting in view of the recent observation suggesting that germline mutations at the human E-cadherin gene are responsible for familial diffuse gastric cancer. ${ }^{30-32}$ Somatic E-cadherin mutations have also been observed at high frequency in sporadic gastric cancers of the diffuse type ${ }^{34,44,55,56}$ and in invasive, lobular breast carcinomas. ${ }^{35,43,45}$ In most cases, these mutations are accompanied by a loss of the second allele. Thus, as a consequence of the complete loss of E-cadherin function, there seems to be a morphologic shift to a diffuse growth pattern. No mutations have been detected in intestinaltype gastric lesions ${ }^{55,57,58}$ and colorectal cancers. ${ }^{59} \mathrm{Nev}-$ ertheless, a high proportion of colorectal and some intestinal-type gastric cancers show reduced expression of E-cadherin. ${ }^{57-62}$ The latter has been explained by a number of mechanisms, including transcriptional down-regulation either by promoter methylation or binding of transcriptional repressors such as Snail, which are upregulated in tumor cells. ${ }^{23,63,64}$ This resembles the situation of the gastrointestinal tumors of the $A p c^{+/ 1638 N} / E-$ $\mathrm{cad}^{+/-}$animals, in which no diffuse growth pattern has been observed while retaining E-cadherin immunoreactivity at reduced levels, which suggests that inactivation of only one E-cadherin allele contributes to tumor development.

At 6-9 months of age, many $A p c^{+/ 1638 \mathrm{~N} / E-c a d^{+/-}}$ animals showed severe signs of morbidity as a result of the high tumor multiplicity. This precluded analysis of the tumor phenotype at later time points. However, at the time of analysis, no obvious differences in histopathologic appearance were observed between the tumors of both genotypes, as also confirmed by the similar tumor size and degree of invasion. No E-cadherin loss was observed among $A p c^{+/ 1638 \mathrm{~N} / E-c a d^{+/-}}$tumors, and E-cadherin expression in the tumors was still detectable by immunohistochemistry. Therefore, the level of E-cadherin in $A p c^{+/ 1638 \mathrm{~N} / E-c a d^{+/-}}$mice seems to suffice to prevent further progression toward a more invasive tumor phenotype compared with the $A p c^{+/ 1638 \mathrm{~N}}$ controls.
However, besides a complete inactivation of E-cadherin, the acquirement of a metastatic phenotype requires the functional dysregulation of additional proteins. ${ }^{65}$

In conclusion, introduction of the E-cadherin mutation in Apc1638N animals affects tumor initiation in the gastrointestinal tract rather than progression toward malignancy. This is most likely a result of the overlapping functions of E-cadherin in controlling both Wnt signal transduction and cell adhesion.

\section{References}

1. Groden J, Thliveris A, Samowitz W, Carlson M, Gelbert L, Albertsen $H$, Joslyn G, Stevens J, Spirio L, Robertson M, Sargeant L, Krapcho K, Wolff E, Burt R, Hughes JP, Warrington J, McPherson J, Wasmuth J, Le Paslier D, Abderrahim H, Cohen D, Leppert M, White R. Identification and characterization of the familial adenomatous polyposis coli gene. Cell 1991;66:589-600.

2. Nishisho I, Nakamura Y, Miyoshi Y, Miki Y, Ando H, Horii A, Koyama K, Utsunomiya J, Baba S, Hedge P, Markham A, Krush AJ, Petersen G, Hamilton SR, Nilbert MC, Levy DB, Bryan TM, Preisinger AC, Smith KJ, Su L-K, Kinzler KW, Vogelstein B. Mutations of chromosome 5q21 genes in FAP and colorectal cancer patients. Science 1991;253:665-669.

3. Su LK, Kinzler KW, Vogelstein B, Preisinger AC, Moser AR, Luongo C, Gould KA, Dove WF. Multiple intestinal neoplasia caused by a mutation in the murine homolog of the APC gene [published erratum appears in Science 1992;256:1114]. Science 1992; 256:668-670.

4. Fodde R, Edelmann W, Yang $\mathrm{K}$, van Leeuwen C, Carlson C, Renault B, Breukel C, Alt E, Lipkin M, Khan PM, Kucherlapati R. A targeted chain-termination mutation in the mouse Apc gene results in multiple intestinal tumors. Proc Natl Acad Sci U S A 1994;91:8969-8973.

5. Oshima M, Oshima H, Kitagawa K, Kobayashi M, Itakura C Taketo M. Loss of Apc heterozygosity and abnormal tissue building in nascent intestinal polyps in mice carrying a truncated Apc gene. Proc Natl Acad Sci U S A 1995;92:4482-4486.

6. Smits R, van der Houven van Oordt W, Luz A, Zurcher C, Jagmohan-Changur S, Breukel C, Khan PM, Fodde R. Apc1638N: a mouse model for familial adenomatous polyposis-associated desmoid tumors and cutaneous cysts. Gastroenterology 1998; 114:275-283.

7. Ichii S, Takeda S, Horii A, Nakatsuru S, Miyoshi Y, Emi M, Fujiwara Y, Koyama K, Furuyama J, Utsunomiya J, Nakamura Y. Detailed analysis of genetic alterations in colorectal tumors from patients with and without familial adenomatous polyposis (FAP). Oncogene 1993;8:2399-2405.

8. Levy DB, Smith KJ, Beazer-Barclay Y, Hamilton SR, Vogelstein B, Kinzler KW. Inactivation of both APC alleles in human and mouse tumors. Cancer Res 1994;54:5953-5958.

9. Luongo C, Moser AR, Gledhill S, Dove WF. Loss of Apc+ in intestinal adenomas from Min mice. Cancer Res 1994;54:59475952.

10. Smits R, Kartheuser A, Jagmohan-Changur S, Leblanc V, Breukel $\mathrm{C}$, de Vries $\mathrm{A}$, van Kranen $\mathrm{H}$, van Krieken $\mathrm{JH}$, Williamson $\mathrm{S}$, Edelmann W, Kucherlapati R, Khan P, Fodde R. Loss of Apc and the entire chromosome 18 but absence of mutations at the Ras and Tp53 genes in intestinal tumors from Apc1638N, a mouse model for Apc-driven carcinogenesis. Carcinogenesis 1997;18: 321-327.

11. Powell SM, Zilz N, Beazer-Barclay Y, Bryan TM, Hamilton SR, Thibodeau SN, Vogelstein B, Kinzler KW. APC mutations occur early during colorectal tumorigenesis. Nature 1992;359:235237. 
12. Polakis $\mathrm{P}$. The adenomatous polyposis coli (APC) tumor suppressor. Biochim Biophys Acta 1997;1332:F127-F147.

13. Smits R, Kielman MF, Breukel C, Zurcher C, Neufeld K, Jagmohan-Changur S, Hofland N, van Dijk J, White R, Edelmann W, Kucherlapati R, Khan PM, Fodde R. Apc1638T: a mouse model delineating critical domains of the adenomatous polyposis coli protein involved in tumorigenesis and development. Genes Dev 1999;13:1309-1321.

14. Willert K, Nusse R. Beta-catenin: a key mediator of Wnt signaling. Curr Opin Genet Dev 1998;8:95-102.

15. Rubinfeld B, Albert I, Porfiri E, Fiol C, Munemitsu S, Polakis P. Binding of GSK3beta to the APC-beta-catenin complex and regulation of complex assembly [see comments]. Science 1996;272: 1023-1026.

16. Morin PJ, Sparks AB, Korinek V, Barker N, Clevers H, Vogelstein $\mathrm{B}$, Kinzler KW. Activation of beta-catenin-Tcf signaling in colon cancer by mutations in beta-catenin or APC [see comments]. Science 1997;275:1787-1790.

17. Nagafuchi A, Takeichi M. Cell binding function of E-cadherin is regulated by the cytoplasmic domain. EMBO J 1988;7:36793684.

18. Ozawa M, Baribault H, Kemler R. The cytoplasmic domain of the cell adhesion molecule uvomorulin associates with three independent proteins structurally related in different species. EMBO J 1989;8:1711-1717.

19. Ozawa M, Ringwald M, Kemler R. Uvomorulin-catenin complex formation is regulated by a specific domain in the cytoplasmic region of the cell adhesion molecule. Proc Natl Acad Sci U S A 1990;87:4246-4250.

20. Kintner $C$. Regulation of embryonic cell adhesion by the cadherin cytoplasmic domain. Cell 1992;69:225-236.

21. Birchmeier W, Behrens J. Cadherin expression in carcinomas: role in the formation of cell junctions and the prevention of invasiveness. Biochim Biophys Acta 1994;1198:11-26.

22. Perl AK, Wilgenbus P, Dahl U, Semb H, Christofori G. A causal role for E-cadherin in the transition from adenoma to carcinoma. Nature 1998;392:190-193.

23. Christofori G, Semb H. The role of the cell-adhesion molecule E-cadherin as a tumour-suppressor gene. Trends Biochem Sci 1999;24:73-76.

24. Hulsken J, Birchmeier W, Behrens J. E-cadherin and APC compete for the interaction with beta-catenin and the cytoskeleton. J Cell Biol 1994;127:2061-2069.

25. Rubinfeld B, Souza B, Albert I, Munemitsu S, Polakis P. The APC protein and E-cadherin form similar but independent complexes with alpha-catenin, beta-catenin, and plakoglobin. J Biol Chem 1995;270:5549-5555.

26. Gumbiner BM. Cell adhesion: the molecular basis of tissue architecture and morphogenesis. Cell 1996;84:345-357.

27. Hynes RO. Cell adhesion: old and new questions. Trends Cell Biol 1999;9:M33-M37.

28. Jawhari AU, Farthing MJ, Pignatelli M. The E-cadherin/epidermal growth factor receptor interaction: a hypothesis of reciprocal and reversible control of intercellular adhesion and cell proliferation [editorial]. J Pathol 1999;187:155-157.

29. Perry I, Hardy R, Tselepis C, Jankowski JA. Cadherin adhesion in the intestinal crypt regulates morphogenesis, mitogenesis, motogenesis, and metaplasia formation. Mol Pathol 1999;52:166168.

30. Guilford P, Hopkins J, Harraway J, McLeod M, McLeod N, Harawira P, Taite H, Scoular R, Miller A, Reeve AE. E-cadherin germline mutations in familial gastric cancer. Nature 1998;392: 402-405.

31. Gayther SA, Gorringe KL, Ramus SJ, Huntsman D, Roviello F, Grehan N, Machado JC, Pinto E, Seruca R, Halling K, MacLeod P, Powell SM, Jackson CE, Ponder BA, Caldas C. Identification of germ-line E-cadherin mutations in gastric cancer families of European origin. Cancer Res 1998;58:4086-4089.

32. Richards FM, McKee SA, Rajpar MH, Cole TR, Evans DG, Jankowski JA, McKeown C, Sanders DS, Maher ER. Germline E-cadherin gene (CDH1) mutations predispose to familial gastric cancer and colorectal cancer. Hum Mol Genet 1999;8:607-610.

33. Becker I, Becker KF, Rohrl MH, Minkus G, Schutze K, Hofler H. Single-cell mutation analysis of tumors from stained histologic slides. Lab Invest 1996;75:801-807.

34. Muta H, Noguchi M, Kanai Y, Ochiai A, Nawata H, Hirohashi S. $\mathrm{E}$-cadherin gene mutations in signet ring cell carcinoma of the stomach. Jpn J Cancer Res 1996;87:843-848.

35. Vos CB, Cleton-Jansen AM, Berx G, de Leeuw WJ, ter Haar NT, van Roy F, Cornelisse CJ, Peterse JL, van de Vijver MJ. E-cadherin inactivation in lobular carcinoma in situ of the breast: an early event in tumorigenesis. Br J Cancer 1997;76:1131-1133.

36. Riethmacher D, Brinkmann V, Birchmeier C. A targeted mutation in the mouse E-cadherin gene results in defective preimplantation development. Proc Natl Acad Sci U S A 1995;92:855-859.

37. Rosai J. Large bowel. In: Grey L, ed. Ackerman's surgical pathology. 8th ed. St. Louis, MO: Mosby, 1996:729-799.

38. Riddell RH, Goldman H, Ransohoff DF, Appelman HD, Fenoglio CM, Haggitt RC, Ahren C, Correa P, Hamilton SR, Morson BC, Sommers SC, Yardley JH. Dysplasia in inflammatory bowel disease: standardized classification with provisional clinical applications. Hum Pathol 1983;14:931-968.

39. Vestweber D, Kemler R. Identification of a putative cell adhesion domain of uvomorulin. EMBO J 1985;4:3393-3398.

40. Ozawa M, Hoschutzky H, Herrenknecht K, Kemler R. A possible new adhesive site in the cell-adhesion molecule uvomorulin. Mech Dev 1991;33:49-56.

41. van der Houven van Oordt CW, Smits R, Williamson SL, Luz A, Khan PM, Fodde R, van der Eb AJ, Breuer ML. Intestinal and extra-intestinal tumor multiplicities in the Apc1638N mouse model after exposure to X-rays. Carcinogenesis 1997;18:21972203.

42. van der Houven van Oordt CW, Smits R, Schouten TG, HouwingDuistermaat JJ, Williamson SL, Luz A, Meera Khan P, van der Eb $\mathrm{AJ}$, Breuer ML, Fodde R. The genetic background modifies the spontaneous and X-ray-induced tumor spectrum in the Apc1638N mouse model. Genes Chromosomes Cancer 1999; 24:191-198.

43. Berx G, Cleton-Jansen AM, Nollet F, de Leeuw WJ, van de Vijver M, Cornelisse C, van Roy F. E-cadherin is a tumour/invasion suppressor gene mutated in human lobular breast cancers. EMBO J 1995;14:6107-6115.

44. Becker KF, Atkinson MJ, Reich U, Becker I, Nekarda H, Siewert JR, Hofler H. E-cadherin gene mutations provide clues to diffuse type gastric carcinomas. Cancer Res 1994;54:3845-3852.

45. Berx G, Becker KF, Hofler H, van Roy F. Mutations of the human E-cadherin (CDH1) gene. Hum Mutat 1998;12:226-237.

46. Smits R, Hofland N, Edelmann W, Geugien M, Jagmohan-Changur S, Albuqurque C, Breukel C, Kucherlapati R, Kielman MF, Fodde R. Somatic Apc mutations are selected upon their capacity to inactivate the beta-catenin downregulating activity. Genes Chromosomes Cancer (in press).

47. Fagotto F, Funayama N, Gluck U, Gumbiner BM. Binding to cadherins antagonizes the signaling activity of beta-catenin during axis formation in Xenopus. J Cell Biol 1996;132:1105-1114.

48. Sanson B, White P, Vincent JP. Uncoupling cadherin-based adhesion from wingless signalling in Drosophila. Nature 1996;383: 627-630.

49. Orsulic S, Peifer M. An in vivo structure-function study of armadillo, the beta-catenin homologue, reveals both separate and overlapping regions of the protein required for cell adhesion and for wingless signaling. J Cell Biol 1996;134:1283-1300.

50. Heasman J, Crawford A, Goldstone K, Garner-Hamrick P, Gum- 
biner B, McCrea P, Kintner C, Noro CY, Wylie C. Overexpression of cadherins and underexpression of beta-catenin inhibit dorsal mesoderm induction in early Xenopus embryos. Cell 1994;79: 791-803.

51. Sadot E, Simcha I, Shtutman M, Ben-Ze'ev A, Geiger B. Inhibition of beta-catenin-mediated transactivation by cadherin derivatives. Proc Natl Acad Sci U S A 1998;95:15339-15344.

52. Orsulic S, Huber O, Aberle H, Arnold S, Kemler R. E-cadherin binding prevents beta-catenin nuclear localization and beta-catenin/LEF-1-mediated transactivation. J Cell Sci 1999;112:12371245.

53. Cox RT, Kirkpatrick C, Peifer M. Armadillo is required for adherens junction assembly, cell polarity, and morphogenesis during Drosophila embryogenesis. J Cell Biol 1996;134:133-148.

54. Hermiston ML, Gordon JI. Inflammatory bowel disease and adenomas in mice expressing a dominant negative $\mathrm{N}$-cadherin. Science 1995;270:1203-1207.

55. Tamura G, Sakata K, Nishizuka S, Maesawa C, Suzuki Y, Iwaya T, Terashima M, Saito K, Satodate R. Inactivation of the E-cadherin gene in primary gastric carcinomas and gastric carcinoma cell lines. Jpn J Cancer Res 1996;87:1153-1159.

56. Machado JC, Soares P, Carneiro F, Rocha A, Beck S, Blin N, Berx $G$, Sobrinho-Simoes M. E-cadherin gene mutations provide a genetic basis for the phenotypic divergence of mixed gastric carcinomas. Lab Invest 1999;79:459-465.

57. Becker KF, Hofler H. Frequent somatic allelic inactivation of the E-cadherin gene in gastric carcinomas. J Natl Cancer Inst 1995; 87:1082-1084.

58. Braungart E, Schumacher C, Hartmann E, Nekarda H, Becker KF, Hofler H, Atkinson MJ. Functional loss of E-cadherin and cadherin-11 alleles on chromosome 16q22 in colonic cancer. J Pathol 1999;187:530-534.

59. Schuhmacher C, Becker I, Oswald S, Atkinson MJ, Nekarda H, Becker KF, Mueller J, Siewert JR, Hofler H. Loss of immunohistochemical E-cadherin expression in colon cancer is not due to structural gene alterations. Virchows Arch 1999;434:489-495.
60. Kinsella AR, Green B, Lepts GC, Hill CL, Bowie G, Taylor BA. The role of the cell-cell adhesion molecule E-cadherin in large bowel tumour cell invasion and metastasis. Br J Cancer 1993;67:904909.

61. Nigam AK, Savage FJ, Boulos PB, Stamp GW, Liu D, Pignatelli M. Loss of cell-cell and cell-matrix adhesion molecules in colorectal cancer. Br J Cancer 1993;68:507-514.

62. van der Wurff AA, ten Kate J, van der Linden EP, Dinjens WN, Arends JW, Bosman FT. L-CAM expression in normal, premalignant, and malignant colon mucosa. J Pathol 1992;168:287291.

63. Batlle E, Sancho E, Franci C, Dominguez D, Monfar M, Baulida J, Garcia De Herreros A. The transcription factor snail is a repressor of E-cadherin gene expression in epithelial tumour cells. Nat Cell Biol 2000;2:84-89.

64. Cano A, Perez-Moreno MA, Rodrigo I, Locascio A, Blanco MJ, del Barrio MG, Portillo F, Nieto MA. The transcription factor snail controls epithelial-mesenchymal transitions by repressing E-cadherin expression. Nat Cell Biol 2000;2:76-83.

65. Streit M, Schmidt R, Hilgenfeld RU, Thiel E, Kreuser ED. Adhesion receptors in malignant transformation and dissemination of gastrointestinal tumors. J Mol Med 1996;74:253-268.

Received September 22, 1999. Accepted June 7, 2000.

Address requests for reprints to: Riccardo Fodde, Medical Genetics Center, Department of Human and Clinical Genetics, Leiden University Medical Center, Wassenaarseweg 72, 2333 AL Leiden, The Netherlands. e-mail: R.Fodde@lumc.nl; fax: (31) 71-5276075.

Supported by grants from the Dutch Cancer Society (94-817, to R.S; C.B., 95-1102, to S.J.-C.); a fellowship from the European Union (P.R.); the Deutsche Krebshilfe (to W.B.); and the Dutch Royal Academy of Sciences (to R.F.).

Dr. Diaz-Cano's current address is: Department of Pathology, St Bartholomew's and the Royal London School of Medicine and Dentistry, London, England. 